\title{
Effects of transient changes in silage dry matter concentration on lactating dairy cows
}

\author{
L. R. McBeth, ${ }^{*}$ N. R. St-Pierre, ${ }^{*} \dagger$ D. E. Shoemaker, $\dagger$ and W. P. Weiss ${ }^{*} \dagger^{1}$ \\ *Department of Animal Sciences Ohio Agricultural Research and Development Center, The Ohio State University, Wooster 44691 \\ †Ohio State University Extension, 1680 Madison Ave., Wooster 44691
}

\begin{abstract}
Transient changes in the dry matter (DM) concentration of silages often occur, which will cause transient changes in the ration. To determine the effects of a transient change in silage DM, 24 Holstein cows (116 d in milk) were used in an 8 replicated $3 \times 3$ Latin square design with 21-d periods. Treatments were (1) control, (2) unbalanced (UNBAL), and (3) balanced (BAL). The control diet was designed to have a consistent dayto-day forage:concentrate ratio of 55:45 on a DM basis. The UNBAL and BAL diets were the same as the control diet for most of the period except during two 3-d bouts when water was added to the silage (simulating a rain event) to cause a 10 -percentage unit decrease in silage DM concentration. During the bouts, the UNBAL diet was the same as that of the control on an as-fed basis, but on a DM basis, the forage:concentrate ratio decreased to $49: 51$, which reduced dietary concentrations of DM (63.9 vs. 66.2\%) and forage NDF (21.0 vs. $23.6 \%$ ), and increased starch (30.4 vs. $28.4 \%$ ). The BAL treatment corrected for the change in silage DM by an increase in the inclusion of wet silage and had the same composition as the control diet on a DM basis, except for ration DM (66.2 vs. $63.9 \%)$. Over the 21 -d period, treatment did not affect DM intake (DMI; 24.0 $\mathrm{kg} / \mathrm{d}$ ); however, DMI of cows on the UNBAL and BAL treatments tended to decrease during the wet bouts, especially during the second bout. The day following both bouts, DMI of cows fed BAL and UNBAL diets were greater than that of cows fed the control diet, which contributed to the lack of a treatment effect on DMI over the entire period. Milk production was greater for the UNBAL than control cows (39.8 vs. 39.3 $\mathrm{kg} / \mathrm{d}$ ) over the 21-d period. That difference was largely caused by increased milk yield during the first bout by cows on the UNBAL diet. Over the 21-d period, milk yield did not differ between control and BAL cows. Some small differences in milk fat and protein concen-
\end{abstract}

Received October 31, 2012.

Accepted February 20, 2013.

${ }^{1}$ Corresponding author: weiss.6@osu.edu trations ( $\leq 0.1$ percentage units) were observed between treatments. Total-tract digestibility of most nutrients was not affected by treatment. Overall, a 10-percentage unit decrease in silage DM over short-term bouts (with or without total mixed ration adjustment) had only minor effects on DMI, milk yield, and composition.

Key words: silage variability, dry matter change, precision feeding

\section{INTRODUCTION}

The nutrient concentrations of feedstuffs vary substantially over short periods of time (Weiss et al., 2012), which can cause variation in the nutrient composition of the TMR. Forages often comprise more than half the diet DM fed to lactating dairy cows (Shaver, 2004), and a change in forage composition could cause a substantial change in the composition of the TMR. Rations are formulated on a DM basis; however, ingredients are included in the mixture on an as-fed basis. Average ranges in the DM concentration of monthly samples of corn and alfalfa silage within a farm (over a 12-mo period) were 9 and 21 percentage units and ranges in daily samples over a 14-d period were 7 and 11 percentage units, respectively (Weiss et al., 2012). These large transient changes in water concentrations in silage could directly affect cows; and if as-fed inclusion rates were not adjusted for changes in DM concentration, the nutrient composition of the TMR would change and that may also affect the cow.

Milk yields and DMI are usually not affected by a long-term (weeks) difference in DM concentrations of TMR (Robinson et al., 1990; Leonardi et al., 2005; Fish and DeVries, 2012). However, the objective of the current experiment was to evaluate transient (days) changes in DM concentration of TMR such as that caused by a rainfall event on an uncovered silo. In previous studies, transient (1- to 3-d) decrease in silage DM of 3 to 8 percentage units decreased short-term DMI and milk production (Mertens and Berzaghi, 2009; Boyd and Mertens, 2010; Boyd and Mertens, 2011). Those studies have only been reported in abstract form and as-fed inclusion rates were not altered so that the concentra- 
tions of multiple nutrients (not just water) in the TMR changed. We hypothesized that a transient decrease in silage DM concentration would reduce DMI and milk yield, and in response to changes in the rumen fermentation (caused by abrupt changes in concentrations of dietary carbohydrates), milk FA would be altered and digestibility reduced when cows were fed a TMR that was not adjusted for the change in silage. However, if inclusion rates were adjusted, the transient change would not affect the cows.

\section{MATERIALS AND METHODS}

\section{Cows, Diets, and Experimental Design}

All procedures involving animals were approved by The Ohio State University Institutional Animal Care and Use Committee (Columbus). Twenty-four Holstein cows were blocked by parity ( 3 squares of multiparous and 5 squares of primiparous) and assigned to 1 of 6 treatment sequences in 8 orthogonally replicated $3 \times 3$ Latin squares with 21-d periods (starting August 6 and ending October 8). At the beginning of the experiment, cows averaged 116 DIM $( \pm 23 \mathrm{~d})$ and BCS of 2.9. Cows were moved into tiestalls and fed the control diet for 10 $\mathrm{d}$ before the first period.

Three dietary treatments were used in this experiment (Tables 1 and 2). The control was formulated to have a consistent forage-to-concentrate $(\mathbf{F}: \mathbf{C})$ ratio of 55:45 (DM basis) throughout the 21-d period. The forage DM consisted of $67 \%$ alfalfa silage and $33 \%$ corn silage (stored in separate glass-lined steel silos). The unbalanced (UNBAL) and balanced (BAL) diets were the same as the control diet for most of the period, except during 2 separate 3 - $\mathrm{d}$ bouts that occurred on $\mathrm{d}$ 3 to 5 and on d 12 to 14 of each period. During those bouts, water was added to both silages to reduce their DM concentration by 10 percentage units. During the bouts, the UNBAL diet was the same as the control diet on an as-fed basis, but the $\mathrm{F}$ : $\mathrm{C}$ ratio was lower on a DM basis (49:51). During the bouts, the BAL diet was corrected for the change in silage DM concentration so that on a DM basis, the $\mathrm{F}$ : $\mathrm{C}$ ratio was the same as that of the control $(55: 45)$ but the $\mathrm{F}: \mathrm{C}$ ratio on an as-fed basis was higher than that of the control and UNBAL treatments.

Cows were fed a TMR once daily and DMI was measured daily. Cows were fed for a target of $5 \%$ feed refusal, and feed refusal averaged $6 \%$ of feed offered (i.e., during bouts, cows did not run out of feed). Cows were milked twice daily and weights were recorded electronically at each milking. Milk samples (a.m. and p.m.) were obtained on $2 \mathrm{~d}$ each week (6 samples per period) so that we had 3 samples (a.m. and p.m.) taken during the bouts and 3 samples taken when all cows were fed the control diet for each period. Cows were weighed and

Table 1. Ingredient composition of the diets (\% of DM)

\begin{tabular}{|c|c|c|c|}
\hline \multirow[b]{2}{*}{ Ingredient } & \multicolumn{3}{|c|}{ Treatment $^{1}$} \\
\hline & Control & UNBAL & BAL \\
\hline Alfalfa silage ${ }^{2}$ & 37.5 & - & - \\
\hline Corn silage $^{2}$ & 17.5 & - & - \\
\hline Wet alfalfa silage ${ }^{3}$ & - & 32.5 & 37.5 \\
\hline Wet corn silage $^{3}$ & - & 16.3 & 17.5 \\
\hline Corn (ground) & 32.6 & 37.1 & 32.6 \\
\hline Treated soybean meal ${ }^{4}$ & 5.0 & 5.7 & 5.0 \\
\hline Dried distillers grains with solubles & 3.0 & 3.4 & 3.0 \\
\hline Soybean hulls & 2.1 & 2.3 & 2.1 \\
\hline Fat (animal-vegetable blend) & 0.89 & 1.02 & 0.89 \\
\hline Trace mineral salt & 0.51 & 0.58 & 0.51 \\
\hline Limestone & 0.27 & 0.31 & 0.27 \\
\hline Magnesium oxide & 0.12 & 0.14 & 0.12 \\
\hline Dicalcium phosphate & 0.08 & 0.09 & 0.08 \\
\hline Mineral and vitamin premix ${ }^{5}$ & 0.53 & 0.61 & 0.53 \\
\hline
\end{tabular}

${ }^{1}$ The control diet was fed to control cows at all times and to all other cows during the non-change periods. Cows on unbalanced (UNBAL) and balanced (BAL) diets were fed a mix of wetted silage during two 3-d bouts. Asfed inclusion rates for ingredients in the TMR for UNBAL cows were the same as for control cows, but as-fed rates were adjusted for the BAL treatment to achieve the same diet as the control treatment on a DM basis.

${ }^{2}$ Nutrient composition (on a DM basis) of alfalfa silage: $53.5 \% \mathrm{DM}, 46.0 \% \mathrm{NDF}$, and $19.1 \% \mathrm{CP}$ and corn silage: $36.4 \%$ DM, $36.0 \% \mathrm{NDF}$, and $35.9 \%$ starch.

${ }^{3}$ Silages were blended and water added to decrease DM concentration 10 percentage units.

${ }^{4}$ Aminoplus (Ag Processing Inc., Omaha, NE).

${ }^{5}$ Contained (as-fed basis) 58.6\% biotin (220 mg/kg; DSM Nutritional Products Inc., Parsippany, NJ), 23.5\% selenium premix (200 mg/kg), 1.9\% Zn-methionine (Zinpro 100; Zinpro Corp., Eden Prairie, MN), 0.7\% copper sulfate, $8.3 \%$ vitamin $\mathrm{E}(44 \mathrm{IU} / \mathrm{g}), 5.1 \%$ vitamin $\mathrm{D}(3,000 \mathrm{IU} / \mathrm{g})$, and $1.9 \%$ vitamin $\mathrm{A}(30,000 \mathrm{IU} / \mathrm{g})$. 
Table 2. Nutrient composition of the diets (DM basis)

\begin{tabular}{|c|c|c|c|}
\hline \multirow[b]{2}{*}{ Item } & \multicolumn{3}{|c|}{ Treatment $^{1}$} \\
\hline & Control & UNBAL & BAL \\
\hline \multicolumn{4}{|l|}{ Nutrient composition $^{2}$} \\
\hline DM, $\%$ & 66.2 & 63.9 & 60.7 \\
\hline $\mathrm{NE}_{\mathrm{L}},{ }^{3} \mathrm{Mcal} / \mathrm{kg}$ & 1.57 & 1.59 & 1.59 \\
\hline $\mathrm{NDF}, \%$ & 30.9 & 29.3 & 30.9 \\
\hline IVNDFD, $\%$ of NDF & 51.2 & 53.0 & 51.2 \\
\hline Forage NDF, \% & 23.6 & 21.0 & 23.6 \\
\hline Starch, \% & 28.4 & 30.4 & 28.4 \\
\hline IVSD, $\%$ & 35.8 & 28.4 & 35.8 \\
\hline $\mathrm{CP}, \%$ & 14.8 & 14.7 & 14.8 \\
\hline Neutral detergent-insoluble CP, \% & 1.8 & 1.8 & 1.8 \\
\hline Acid detergent-insoluble CP, $\%$ & 0.8 & 0.8 & 0.8 \\
\hline Long-chain FA (LCFA), \% & 3.88 & 4.08 & 3.88 \\
\hline C16:0, g/100 g of LCFA & 16.08 & 16.19 & 16.08 \\
\hline $\mathrm{C} 18: 0, \mathrm{~g} / 100 \mathrm{~g}$ of LCFA & 3.65 & 3.77 & 3.65 \\
\hline cis-9 C18:1, g/100 g of LCFA & 15.65 & 16.80 & 15.65 \\
\hline $\mathrm{C} 18: 2, \mathrm{~g} / 100 \mathrm{~g}$ of LCFA & 28.50 & 29.48 & 28.50 \\
\hline $\mathrm{C} 18: 3, \mathrm{~g} / 100 \mathrm{~g}$ of LCFA & 8.04 & 7.41 & 8.04 \\
\hline Other and unidentified, $\mathrm{g} / 100 \mathrm{~g}$ of LCFA & 28.08 & 26.35 & 28.08 \\
\hline Ash, \% & 6.8 & 6.7 & 6.8 \\
\hline $\mathrm{Ca}, \%$ & 0.73 & 0.74 & 0.73 \\
\hline $\mathrm{P}, \%$ & 0.35 & 0.35 & 0.35 \\
\hline $\mathrm{Mg}, \%$ & 0.24 & 0.25 & 0.24 \\
\hline \multicolumn{4}{|l|}{ Particle size ${ }^{4}$} \\
\hline Top screen, $\%$ & 6.3 & 3.7 & 6.4 \\
\hline Middle screen, $\%$ & 39.7 & 39.8 & 41.2 \\
\hline Pan, $\%$ & 54.0 & 56.5 & 52.5 \\
\hline
\end{tabular}

${ }^{1}$ The control diet was fed to control cows at all times and to all other cows during the non-change periods. Cows on unbalanced (UNBAL) and balanced (BAL) diets were fed a mix of wetted silage during two 3-d bouts. Asfed inclusion rates for ingredients in the TMR for UNBAL cows were the same as for control cows, but as-fed rates were adjusted for the BAL treatment to achieve the same diet as the control treatment on a DM basis. ${ }^{2}$ IVNDFD = in vitro NDF disappearance $(30 \mathrm{~h}) ; \mathrm{IVSD}=$ in vitro starch disappearance $(4 \mathrm{~h})$.

${ }^{3} \mathrm{The}_{\mathrm{NE}}$ was calculated (NRC, 2001) using mean DMI for control cows and bout mean DMI for UNBAL and BAL cows.

${ }^{4}$ Penn State Particle Separator (The Pennsylvania State University, University Park), expressed on an as-fed basis.

body condition scored at the beginning of the trial and at the end of each period. All cows in all periods were scored independently by 3 people.

\section{Digestibility}

Two squares of multiparous cows from the production trial were chosen a priori to measure nutrient digestibility via total collection of feces and urine for 4 d. Collection periods were conducted concurrent with the production study in specially designed tiestalls (equipped with individual water bowls and water meters) and started the first day of the first bout of each period (d 3 of each period). Feed intake and output of feces, urine, and milk were measured and sampled (Weiss et al., 2009). Silage, fecal, and refusal samples were lyophilized and ground through a 1-mm screen (Wiley mill; Arthur A. Thomas Co., Philadelphia, PA). Concentrates were neither dried nor ground. Dried ground samples of feeds, feces, and refusals were as- sayed for DM, ash, CP, and NDF as described below (except the CP assay that was conducted on wet fecal samples immediately at the end of the collection period). Samples of milk and acidified urine $(\mathrm{pH}<5)$ were assayed for $\mathrm{CP}$ as described below.

\section{Sampling and Analysis}

For the first 2 wk of the first period, silages were sampled twice weekly and DM was measured (drying overnight at $100^{\circ} \mathrm{C}$ ). To avoid missing an unexpected change in silage DM, both silages were sampled daily starting on d 14 of the first period and assayed daily for DM. When silage DM changed, as-fed inclusion rates were changed to maintain formulation goals.

Separate silage and concentrate samples were obtained weekly and composited by period. Those silage samples were dried at $55^{\circ} \mathrm{C}$ for $48 \mathrm{~h}$ and then ground through a 1-mm screen (Wiley mill; Arthur A. Thomas Co.); concentrate samples were not ground or oven 
dried. Feed samples were analyzed for NDF (Ankom ${ }^{200}$ Fiber Analyzer; Ankom Technology Corp., Fairport, NY) with sodium sulfite and amylase (Sigma A3306; Sigma Diagnostics, St. Louis, MO), ash, CP (AOAC International, 2000; 984.13.4.2.09), ADF (AOAC International, 2000; 973.18.4.6.03), sulfuric acid lignin (Van Soest et al., 1991), neutral- and acid-detergent-insoluble CP, starch (Weiss and Wyatt, 2000), and long-chain FA (Weiss and Wyatt, 2003). Samples of the 3 TMR were constructed from dried samples of forages and concentrates and were analyzed for $30-\mathrm{h}$ in vitro NDF digestibility (Goering and Van Soest, 1970) and 4-h in vitro starch digestibility by Cumberland Valley Analytical Services (Hagerstown, MD). Silage samples were dry ashed and concentrate samples were acid digested, and mineral analyses were conducted using an inductively coupled plasma spectrograph [Service Testing and Research (STAR) Laboratory, Ohio Agricultural Research and Development Center, Wooster, $\mathrm{OH}]$. Diet particle size distribution was measured using a Penn State Particle Separator (The Pennsylvania State University, University Park). In each period, feed refusals of cows on UNBAL and BAL diets were sampled once during each bout, and refusals from all cows (including control cows) were sampled once during the non-change phases and analyzed for DM.

Composited milk samples (a.m. and p.m.) were analyzed for fat, true protein, lactose (B2000 infrared analyzer, filters A+B; Bentley Instruments, Chaska, MN), and MUN (Skalar SAN Plus segmented flow analyzer; Skalar Inc., Norcross, GA) by DHI Cooperative Inc. (Columbus, OH). Milk fat was removed from a subsample of the a.m. sample and the milk FA profile was determined using a 2-step procedure for methylation (Jenkins, 2000) with separation by gas-liquid chromatography using a CP-SIL88 capillary column $(100 \mathrm{~m}$ $\times 0.25 \mathrm{~mm} \times 0.2-\mu \mathrm{m}$ film thickness; Varian Inc., Palo Alto, CA).

\section{Statistical Analysis}

One cow on the control diet (not assigned to digestibility measurement) was removed during the first period due to injury and her data were discarded. Another cow was substituted during the second and third periods. One cow on the UNBAL diet and one cow on the BAL diet in the same block had their treatments accidentally switched during the first bout of the second period. All production data from those 2 cow-periods were discarded. Those 2 cows were used for digestion measurement and their digestibility data was used but was coded to reflect the treatments they actually received, giving 2 observations per treatment for the second period.
Three models were used to analyze the data using PROC MIXED of SAS (v9.3; SAS Institute Inc., Cary, NC). The first model included the fixed effects of treatment ( $2 \mathrm{df})$, parity (1 df), period (2 df), and all possible interactions, and the random effects of cow nested within parity (22 df) and residual error (32 df), and was used to analyze intake, milk production, and composition data (averaged over the 21-d period), nutrient digestibility (the model did not include parity because only multiparous cows were used in the digestion experiment), BCS, and BW. The coefficient of variation for daily milk yield and DMI, and twice-weekly milk fat and milk protein was calculated within cow over the 21 $\mathrm{d}$ of each period, and analyzed as an independent variable. A priori, treatment effects were partitioned into 2 contrasts: control versus UNBAL and control versus BAL. To examine transient effects on intake and milk yield, the second model included the fixed effects of treatment ( $2 \mathrm{df})$, day (20 df, repeated measure), treatment $\times$ day, and period ( $2 \mathrm{df})$, and the random effects of cow nested within parity $(22 \mathrm{df})$, treatment $\times$ period $\times$ cow $(44 \mathrm{df})$, and the residual error. A first-order autoregressive structure was used, because it resulted in the lowest Bayesian information criteria. The SLICE $=\mathrm{DAY}$ option of the LSMEANS statement was used to determine the days when treatment had an effect $(P$ $<0.10$ ). Fisher's protected least significant difference was used to compare treatment means on those days. Because milk composition was only measured on $6 \mathrm{~d}$ during each period, those observations were divided into 2 phases (non-change and bout) and averaged within phase. Those data were analyzed using a model that included the fixed effects of treatment (2 df), parity (1 df), period (2 df), phase (non-change or bout, $1 \mathrm{df}$ ), and all interactions, and the random effects of cow $(22 \mathrm{df})$, cow $\times$ period $(44 \mathrm{df})$, and residual error $(82 \mathrm{df})$. Phase was analyzed as a repeated measure nested within period with compound symmetry as the covariance structure, because it resulted in the lowest Bayesian information criteria. Treatment effects were partitioned into 5 contrasts: non-change versus bout for each treatment (3 contrasts), control versus UNBAL (both during the bouts), and control versus BAL (both during the bouts).

\section{RESULTS AND DISCUSSION}

Day-to-day variation in DM concentrations (Figure 1) of the alfalfa $(\mathrm{CV}=7.4 \%)$ and corn silages (CV $=6.3 \%$ ) was similar to previously observed variation (Weiss et al.., 2012). During the bouts, DM concentrations of the TMR averaged $66.2,63.9$, and $60.7 \% \mathrm{DM}$ for control, UNBAL, and BAL diets, respectively. Not accounting for changes in silage DM caused the con- 


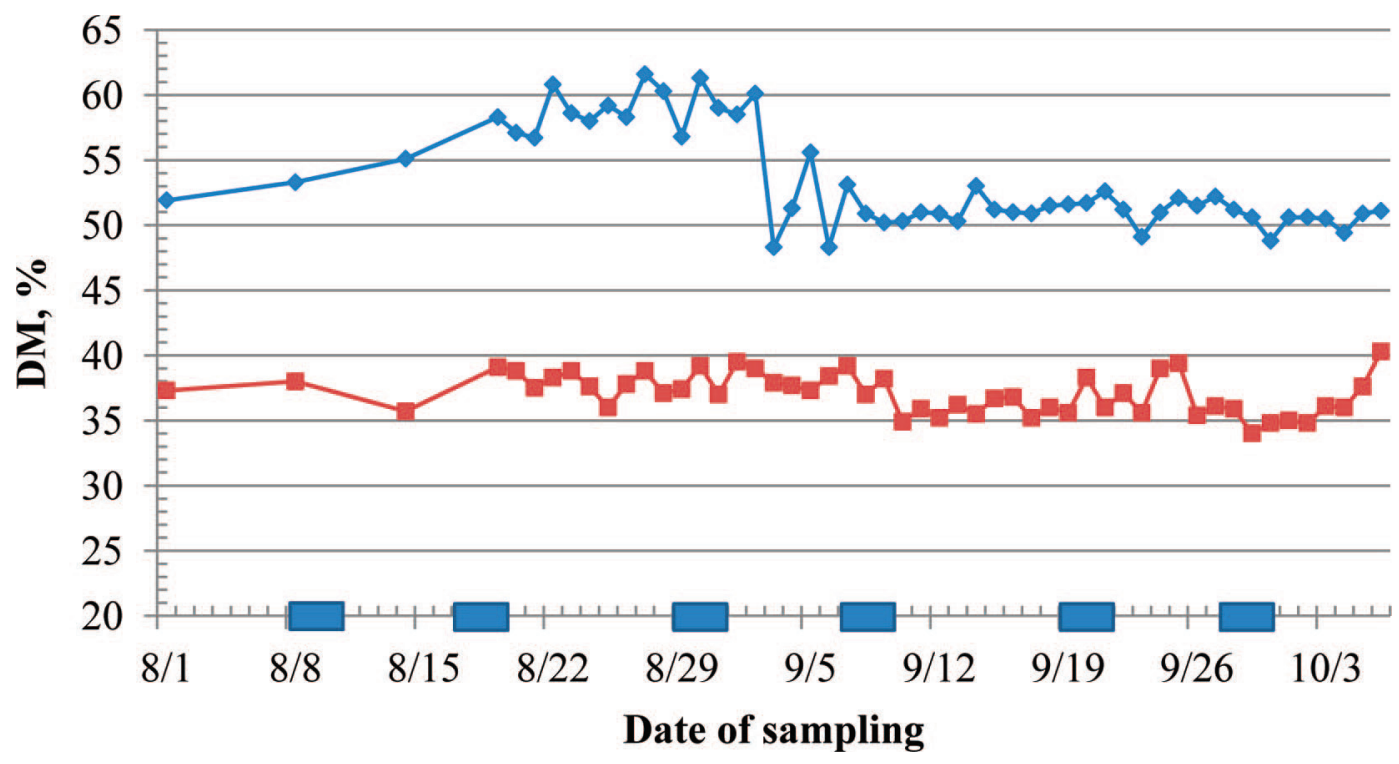

Figure 1. Concentrations of DM in unwetted alfalfa (blue line with diamonds) and corn (red line with squares) throughout the experiment. The blue boxes on the $\mathrm{x}$-axis designate the times when some cows were fed wetted silage. The mean, SD, and range for alfalfa were $53.5 \%, 4.0$, and 13.3 percentage units, respectively, and $37.1 \%, 1.6$, and 6.3 percentage units, respectively, for the corn silage. Color version available in the online PDF.

centrations of NDF and forage NDF to decrease by 1.6 and 2.6 percentage units and increased the starch concentration by 2 percentage units in the UNBAL diet (Table 2). Concentrations of $\mathrm{CP}$ of all treatments were lower than intended because the $\mathrm{CP}$ of the alfalfa silage decreased shortly after the experiment started. The concentration of $\mathrm{CP}$ in these diets was not likely the limiting nutrient because cows were in positive $\mathrm{N}$ balance (discussed below).

\section{Overall Production Measures}

Treatment did not affect BW or BW change (Table 3 ). Over the 21-d period, mean DMI did not differ between control and UNBAL cows or between control and BAL cows (Table 3). Day-to-day variation in DMI (as measured by $\mathrm{CV}$ ) was greater for BAL $(P<0.01)$ than for control cows but did not differ between control and UNBAL cows. Based on studies (Robinson et al., 1990; Leonardi et al., 2005; Fish and DeVries, 2012) that altered the DM concentration of the TMR over longer periods (weeks), we did not expect a difference in DMI between control and BAL treatments. However, the general lack of an effect of treatment on DMI could be because diets were the same for all cows for 15 of the $21 \mathrm{~d}$ in each period. Diets only differed during the two 3-d bouts. Previously (Mertens and Berzaghi, 2009; Boyd and Mertens, 2010), a 1- to 3-d decrease in DM concentration of a TMR decreased DMI for $1 \mathrm{~d}$, but no differences among treatments were observed over the 8-d measurement period. The lack of a difference between control and UNBAL cows could be because the change in nutrient composition of the UNBAL diet (Table 2) was not great enough. Alternatively, the lower concentration of forage NDF in that diet (during the bouts), which could have reduced rumen fill and allowed those cows to eat more (Allen, 2000), was counteracted by the increase in starch concentration, which may have limited DMI via propionate (Allen et al., 2009).

Milk production (Table 3) for UNBAL cows was greater than for control cows $(P=0.05)$, but no differences were observed between BAL and control cows. Day-to-day variation in milk production was similar among treatments. Neither contrast was significant $(P>0.2)$ for milk protein or lactose concentrations; however, yields of milk protein $(P<0.01)$ and lactose $(P<0.05)$ were greater for UNBAL than control cows because of increased milk yield. The concentrations, but not yields, of milk fat and milk energy were lower for cows fed the BAL diet compared with the control diet. The concentration of MUN was greater $(P<0.04)$ for UNBAL and BAL cows compared with control cows, but the differences were small $(0.2$ to $0.5 \mathrm{mg} /$ $\mathrm{dL}$ greater) and likely have little biological importance. Average MUN values for all treatments were low, but still within an acceptable range to maximize milk production while minimizing the environmental impact of nitrogen (Kohn et al., 2002). The increased milk and component yields for the UNBAL cows are likely caused 
Table 3. Effects of two 3-d bouts of feeding wetted silage to dairy cows over a 21-d period

\begin{tabular}{|c|c|c|c|c|c|c|c|}
\hline Item & \multicolumn{3}{|c|}{ Treatment $^{1}$} & SEM & $\mathrm{SED}^{2}$ & \multicolumn{2}{|c|}{$P$-value ${ }^{3}$} \\
\hline BW change, $\mathrm{kg} / \mathrm{d}$ & 0.31 & 0.34 & 0.57 & 0.175 & 0.247 & 0.90 & 0.30 \\
\hline DMI, $\mathrm{kg} / \mathrm{d}$ & 24.0 & 24.1 & 23.9 & 0.41 & 0.19 & 0.83 & 0.52 \\
\hline Milk, kg/d & 39.3 & 39.8 & 39.7 & 0.81 & 0.31 & 0.05 & 0.12 \\
\hline Milk fat, $\%$ & 3.46 & 3.41 & 3.33 & 0.102 & 0.061 & 0.43 & 0.04 \\
\hline Milk fat, $\mathrm{kg} / \mathrm{d}$ & 1.36 & 1.35 & 1.32 & 0.043 & 0.024 & 0.74 & 0.09 \\
\hline Milk protein, \% & 2.79 & 2.81 & 2.79 & 0.043 & 0.015 & 0.20 & 0.69 \\
\hline Milk protein, $\mathrm{kg} / \mathrm{d}$ & 1.09 & 1.11 & 1.10 & 0.017 & 0.009 & 0.01 & 0.12 \\
\hline Lactose, $\%$ & 4.87 & 4.88 & 4.88 & 0.036 & 0.011 & 0.42 & 0.84 \\
\hline Lactose, $\mathrm{kg} / \mathrm{d}$ & 1.91 & 1.94 & 1.93 & 0.036 & 0.016 & 0.05 & 0.21 \\
\hline Milk protein percentage & 3.2 & 2.8 & 3.0 & 0.25 & 0.34 & 0.22 & 0.58 \\
\hline
\end{tabular}

${ }^{1}$ The control diet was fed to control cows at all times and to all other cows during the non-change periods. Cows on unbalanced (UNBAL) and balanced (BAL) diets were fed a mix of wetted silage during two 3-d bouts. As-fed inclusion rates for ingredients in the TMR for UNBAL cows were the same as for control cows, but as-fed rates were adjusted for the BAL treatment to achieve the same diet as the control treatment on a DM basis.

${ }^{2}$ Standard error of the difference.

${ }^{3}$ Contrasts: $\mathrm{C}$ vs. $\mathrm{U}=$ control versus UNBAL; $\mathrm{C}$ vs. $\mathrm{B}=$ control versus BAL.

${ }^{4}$ Calculated from milk fat, protein, and lactose (NRC, 2001).

${ }^{5} \mathrm{CV}=$ coefficient of variation calculated from daily (DMI and milk) or twice-weekly (fat and protein) measures within each cow.

by increased $\mathrm{NE}_{\mathrm{L}}$ intake caused by replacing a portion of the NDF with starch. The decrease in milk fat for cows fed the BAL diet compared with the control diet was responsible for the change in milk energy concentration, but the reason why treatment had an effect on either variable is unknown. The BAL diet was about 6 percentage units wetter than the control diet (all other nutrients were equal) on only 6 of the $21 \mathrm{~d}$ in each period. In previous studies using silage-based TMR, DM concentration had no effect on milk fat concentration (Robinson et al., 1990; Fish and DeVries, 2012).

\section{Transient Changes in Intake and Milk Production}

Over the 21-d period, treatment did not markedly affect DMI or milk yield; however, treatment did affect the across-day patterns of intake and milk yield (Figures 2, 3, and 4). With the exception of the first day after each bout, treatment had no effect on DMI on any day when all cows were fed the same diet, but during the bouts when some cows were fed wetted silage, treatment often affected DMI. On the first day of both bouts, cows fed the BAL diet had lower $(P<0.10)$ DMI than control cows, showing that an abrupt addition of water to silage, without any other change in nutrient composition caused a transient depression in DMI. The BAL diet depressed DMI (compared with the control diet) only on the first day of bout 1 , but DMI was lower $(P<0.10)$ on all $3 \mathrm{~d}$ in the second bout. Cows on the UNBAL diet had similar DMI as control cows during the first bout, but DMI for those cows was less than for control cows $(P<0.10)$ on the first day of the second bout. In previous research, an 8-percentage unit decrease in silage DM through water addition caused between a 0.8 and $2.4 \mathrm{~kg}$ decrease in DMI on the first day wet silage was fed in a TMR that was not adjusted for the change in silage DM (Mertens and Berzaghi, 2009; Boyd and Mertens, 2010). No differences in DMI were reported after that initial decrease, even when wet silage was still fed. Even a 3-percentage unit decrease in silage DM through water addition caused between $0.7-$ and $2.1-\mathrm{kg}$ decreases in DMI on the first day wet silage was fed in a transiently unbalanced TMR (Boyd and Mertens, 2011). The overall greater negative effects of the second bout than the first bout could indicate cumulative effects of diet change. A likely reason DMI during the bouts was usually greater $(P<0.10)$ for the UNBAL than the BAL diet was that the reduced forage NDF concentration in the UNBAL diet countered the negative effects of increased water concentration. 
However, the UNBAL diet also had less added water than the BAL diet (Table 2). A consistent response for cows fed UNBAL or BAL was that DMI was 1 to $1.5 \mathrm{~kg}$ greater $(P<0.10)$ than for those fed the control diet on the first day after both bouts (i.e., a time when all cows were fed the same diet). This apparent overcompensation in DMI on the days following the bouts was a reason that treatment did not greatly affect overall DMI (Table 3). The previous studies did not report whether DMI increased after returning to the non-change silage (Mertens and Berzaghi, 2009; Boyd and Mertens, 2010; Boyd and Mertens, 2011).

As-fed intakes for BAL and UNBAL followed essentially identical patterns (Figure 3) and were higher $(P<0.10)$ than as-fed intakes by control cows during both bouts. However, the maximum response did not occur until the second or third day of feeding the wet silage and maximum as-fed intakes continued until $1 \mathrm{~d}$ after the cows were changed back to the control diet. The initial lag may have been caused by the rumen and gastrointestinal tract being partially filled with the previous day's TMR or for some other reason cows did not immediately sense the reduced concentrations of nutrients in the wetted TMR, but then adjusted the amount of feed consumed to maintain nutrient intake for the remaining days of the bouts. The 1-d lag in reducing as-fed intake after cows changed back to the control diet could be caused by the same factors causing the initial lag (e.g., the rumen is partially filled with wet TMR). Overall, cows responded to changes in diet DM concentration, but responses were not immediate.

Milk production did not follow a consistent pattern over days (Figure 4). During the first bout, cows fed the UNBAL diet had higher milk yield $(P<0.10)$ than control cows on the last day wet silage was fed and the following day when those cows were switched back to the control diet. Cows on the UNBAL diet also had greater milk yield on $\mathrm{d} 8$ (this was when all cows were fed the control diet). Cows fed the BAL diet had greater $(P<0.10)$ milk yield than control cows on $\mathrm{d} 8$ and on the last day of the second bout. Previously, Mertens and Berzaghi (2009) and Boyd and Mertens (2010) reported a 0.9 - to $2.6-\mathrm{kg}$ decrease in milk yield on the day following an 8-percentage unit decrease in silage DM concentration caused by water addition, but no effect on milk yield after a 3-percentage unit decrease in silage DM concentration (Boyd and Mertens, 2011). Those studies have only been reported in abstract form; therefore, procedural details are limited, making determining reasons for the differences observed in our study compared with those previous experiments difficult. Potential reasons include differences in original silage DM concentrations, type of silage, and amount of feed offered. In our experiment, the amount of feed offered
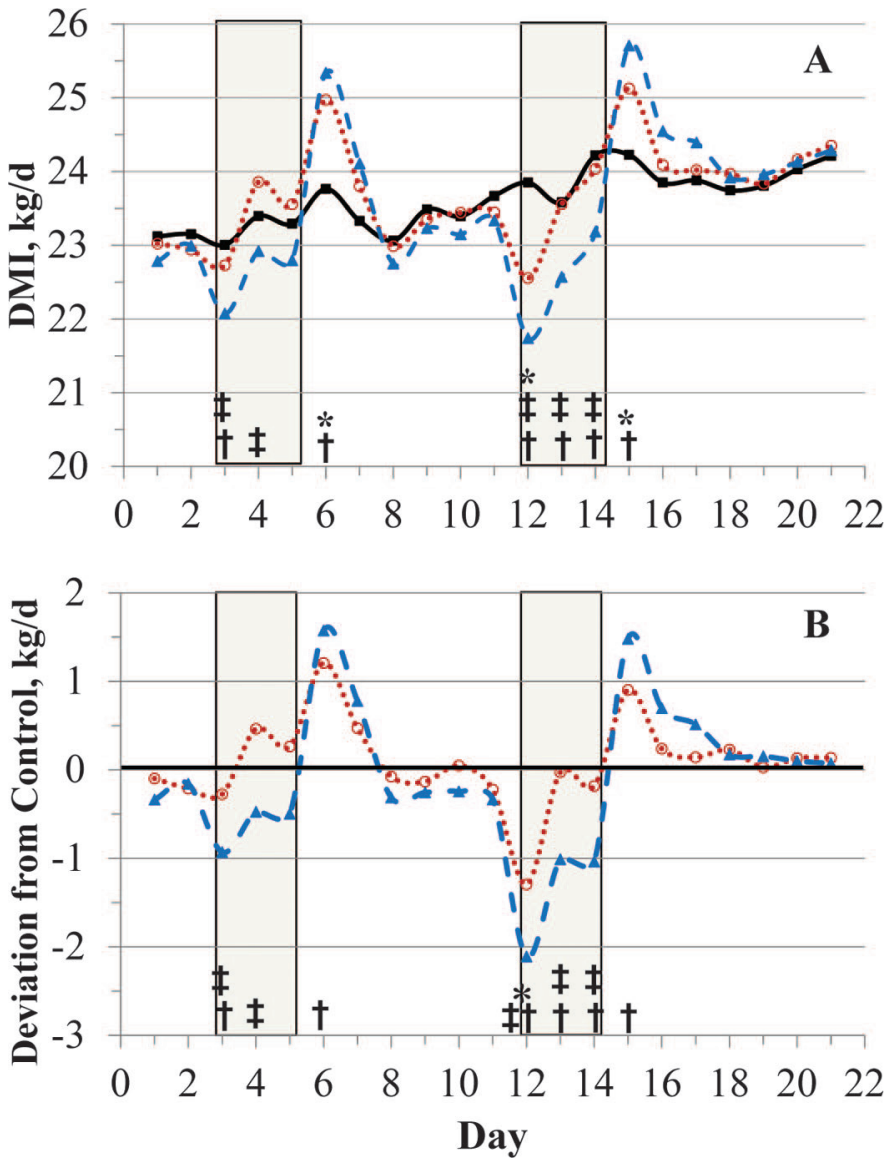

Figure 2. Effects of two 3-d bouts of wet silage on (A) daily DMI and (B) daily DMI deviation from the control over a 21-d period. Control (black solid line with squares) cows were fed a consistent diet over the 21 -d period. The other 2 groups also were fed the control diet except during two 3-d bouts (gray columns; d 3-5 and 12-14) when they were fed wetted silage. During those bouts, unbalanced (UNBAL) cows (open circles with dotted red line) were fed the same as control cows on an as-fed basis (but not on a DM basis). Balanced (BAL) cows (triangles with blue dashed line) were fed the same diet as control cows on a DM basis by adjusting as-fed amounts to account for the change in DM. ${ }^{*}=$ UNBAL versus control: $P<0.1 ; \dagger=\mathrm{BAL}$ versus control: $P<0.1 ; \ddagger=\mathrm{UNBAL}$ versus BAL: $P<0.01$. Color version available in the online PDF.

was increased during the bouts so that adequate DM was available to the cows on all days, but it is unknown whether this occurred in Mertens and Berzaghi (2009) and Boyd and Mertens (2010).

\section{Transient Changes in Milk Composition}

Overall, no major changes in milk composition occurred during the bouts (Table 4). Milk fat concentration increased during the wetted silage bouts for BAL cows; however, milk fat concentration also increased for control cows, suggesting that the change in milk fat percentage was not caused by the transient change in 

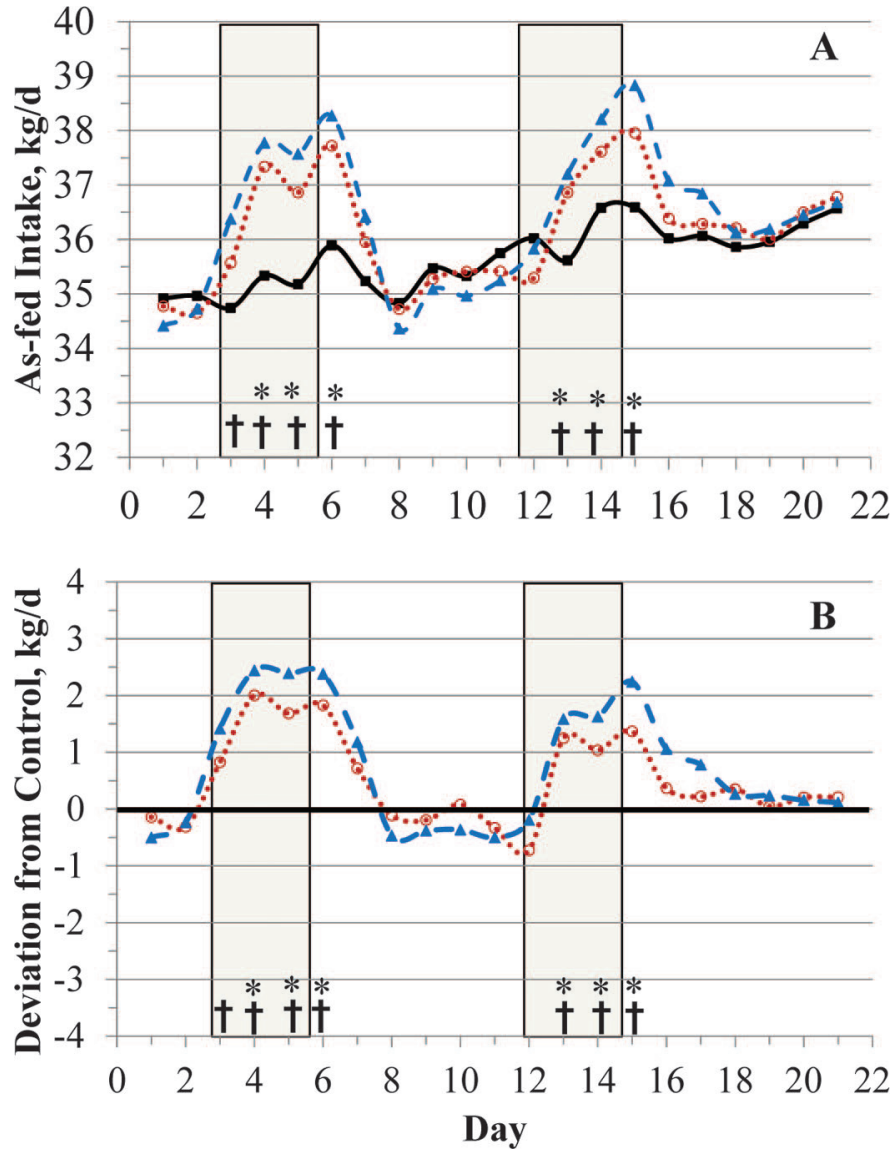

Figure 3. Effects of two 3-d bouts of wet silage on (A) daily as-fed intake and (B) daily as-fed intake deviation from the control over a 21-d period. Control (black solid line with squares) cows were fed a consistent diet over the $21-\mathrm{d}$ period. The other 2 groups also were fed the control diet except during two 3-d bouts (gray columns; $\mathrm{d} 3-5$ and 12-14) when they were fed wetted silage. During those bouts, unbalanced (UNBAL) cows (open circles with red dotted line) were fed the same as control cows on an as-fed basis (but not on a DM basis). Balanced (BAL) cows (triangles with blue dashed line) were fed the same diet as control cows on a DM basis by adjusting as-fed amounts to account for the change in DM. ${ }^{*}=$ UNBAL versus control: $P<$ $0.1 ; \dagger=$ BAL versus control: $P<0.1$. Color version available in the online PDF.

silage DM. The minor decrease in concentration of lactose during the bouts for UNBAL cows may have been caused by dilution because no difference was observed in milk lactose yield between the bout and the control periods. For UNBAL cows, milk protein concentration $(P<0.01)$ and yield $(P<0.10)$ were lower when wetted silage was fed than when those cows were fed the control diet. During the bouts when wetted silage was fed, the starch concentration of the diet was greater for the UNBAL treatment, which can result in increased milk protein concentrations (Ipharraguerre and Clark, 2003). Feeding wetted silage in the BAL treatment did not affect milk protein concentration or yield.
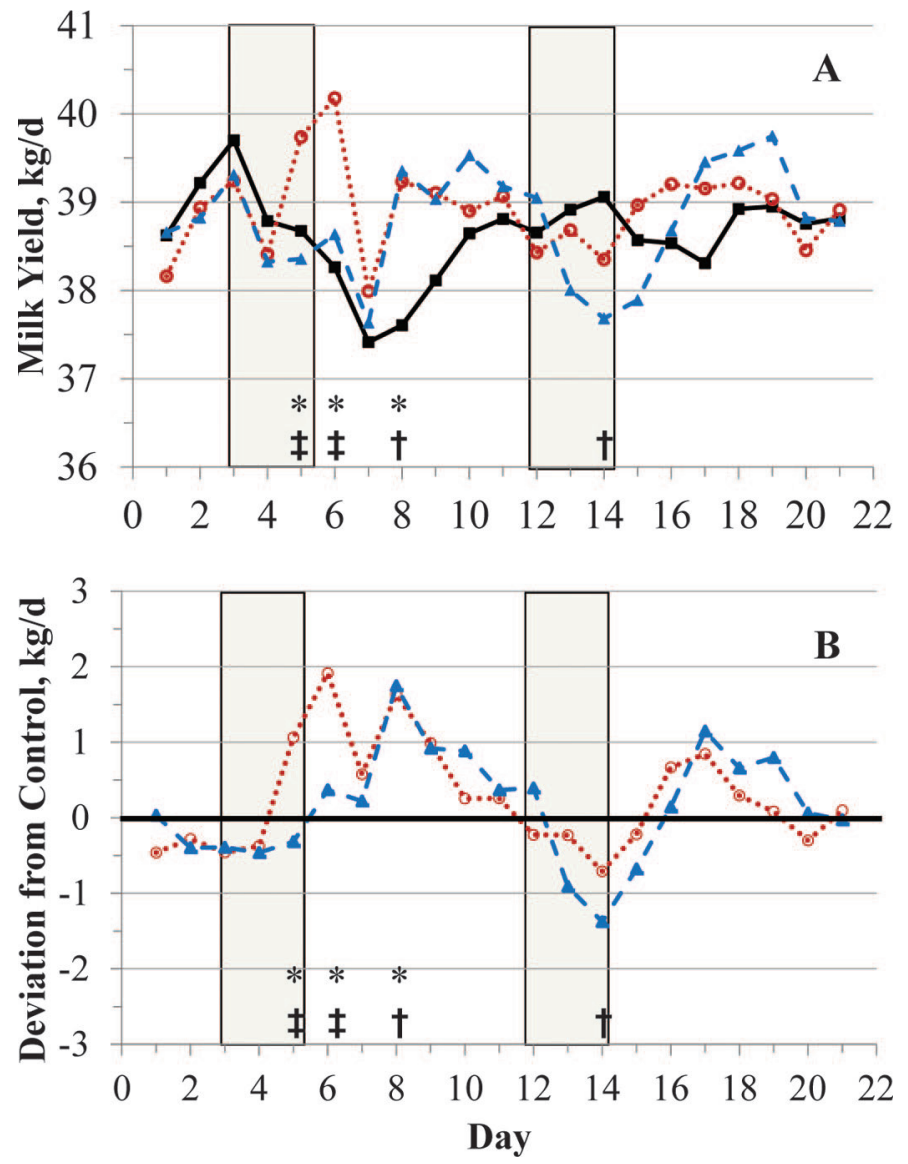

Figure 4. Effects of two 3-d bouts of wet silage on (A) daily milk yields and (B) daily milk yield deviation from the control over a 21-d period. Control (solid black line with squares) cows were fed a consistent diet over the 21-d period. The other 2 groups also were fed the control diet except during two 3-d bouts (gray columns; d 3-5 and 12-14) when they were fed wetted silage. During those bouts, unbalanced (UNBAL) cows (open circles with red dotted line) were fed the same as control cows on an as-fed basis (but not on a DM basis). Balanced (BAL) cows (triangles with blue dashed line) were fed the same diet as control cows on a DM basis by adjusting as-fed amounts to account for the change in DM. ${ }^{*}=\mathrm{UNBAL}$ versus control: $P<0.1$; $\dagger=$ BAL versus control: $P<0.1 ; \ddagger=\mathrm{UNBAL}$ versus BAL: $P<0.01$. Color version available in the online PDF.

\section{Milk FA Profile}

Milk FA (percentage of total milk FA) during the wetted bout rarely differed from concentrations measured during the non-change phase for any treatment (data not shown). The concentration of trans-10, cis-12 CLA was greater during the bouts than during the non-change phases for the BAL treatment (0.014 vs. $0.017 \mathrm{~g} / 100 \mathrm{~g}$ of total FA); however, a similar difference was observed for the control treatment ( 0.012 vs. $0.015 \mathrm{~g} / 100 \mathrm{~g}$ of total FA). Over the entire period (i.e., bout and non-change phases combined), the relative concentrations of many FA were affected by treatment but differences were generally small (Table 5). The 
concentrations of trans- $6+8,-9$, and -10 C18:1 FA were greater for the BAL and UNBAL treatment than for the control treatment. Increased concentrations of some trans FA can indicate a rumen upset such as that caused by ruminal acidosis (Griinari et al., 1998). The oddchain FA $(\mathrm{C} 15: 0$ and $\mathrm{C} 17: 0)$ were greater $(P<0.02)$ for the BAL treatment than for the control treatment. Relationships between milk fat odd- and branchedchain FA and rumen fermentation patterns producing different proportions of VFA have been shown (Vlaeminck et al., 2006a,b; Cabrita et al., 2007; Colman et al., 2010; Fievez et al., 2011). During acidotic rumen conditions, iso C14:0 decreases and C15:0 and C17:0 increase compared with previously normal conditions or healthy herd mates (Fievez et al., 2011). The overall pattern of milk FA (i.e., trans, iso, and odd-chain FA) for UNBAL and especially BAL cows compared with control cows suggest that the transient changes in diet DM caused some disruption of normal rumen conditions. The UNBAL treatment, which we hypothesized would be more disruptive because concentrations of diet DM, starch, and NDF changed during the bouts, did result in increased concentrations of many of the trans $\mathrm{FA}$, but it did not increase $\mathrm{C} 15: 0$ and $\mathrm{C} 17: 0$. The concentration of $\mathrm{C} 16: 0$ was slightly lower $(P<0.02)$ compared with the control treatment for both BAL and UNBAL treatments. This could suggest a decrease in de novo FA synthesis, but no difference was observed in short-chain $(<16 \mathrm{C})$ FA. Stearoyl-CoA desaturase is inhibited when low-forage/high-grain and low-forage/ high-PUFA diets are fed, and during abomasal infusions of trans-10,cis-12 CLA (Baumgard et al., 2002; Peterson et al., 2003; Harvatine and Bauman, 2006). Based on the desaturase indices, that enzyme may have been slightly inhibited by the BAL diet compared with the control diet, but UNBAL had no effect on desaturase indices. Although differences were small, this again suggests that the diet in which only DM concentration changed had a greater effect than did the diet in which the concentration of DM and other nutrients changed.

\section{Nutrient Digestibility and Water Intake}

The digestion trial was conducted from d 3 to 6 of each period, which encompassed the entire first bout plus the following day. Cows on the UNBAL diet had greater DMI $(P<0.09)$ than control cows (Table 6$)$, although no difference in DMI was observed for the production study (Table 3). The difference between results is likely because the digestion trial diets differed on 3 of the $4 \mathrm{~d}$, but during the production study, diets differed only 6 of $21 \mathrm{~d}$. Fecal, fecal water, and total manure output were not affected by treatment, but urine output tended to be greater $(P<0.10)$ for 
Table 5. Effects of two 3-d bouts of feeding wetted silage to dairy cows on selected milk FA over a 21-d period (g/kg of total FA)

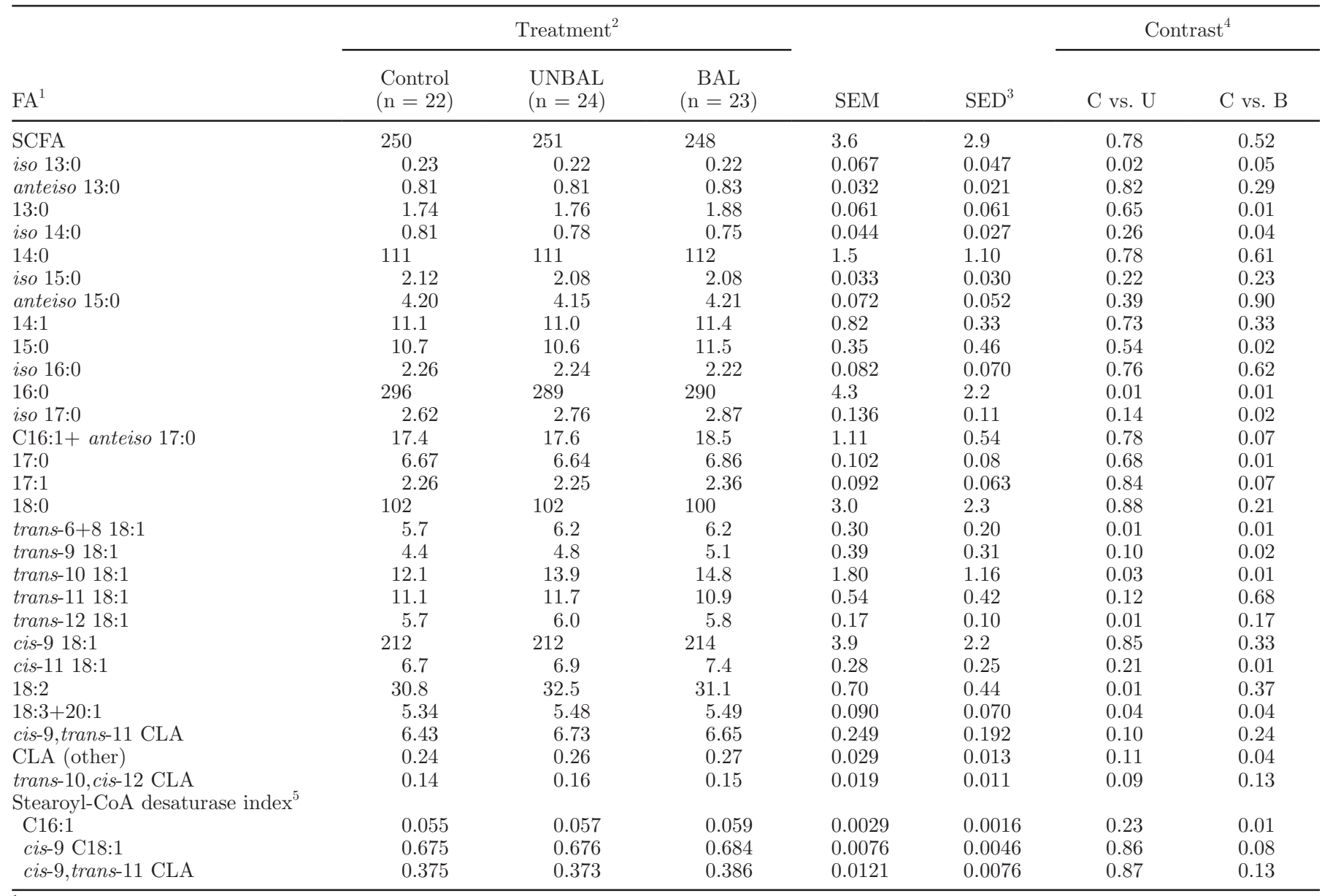

${ }^{1}$ Number of carbons:number of double bonds. SCFA = short-chain FA $(<16 \mathrm{C})$.

${ }^{2}$ The control diet was fed to control cows at all times and to all other cows during the non-change periods. Cows on unbalanced (UNBAL) and balanced (BAL) diets were fed a mix of wetted silage during two 3-d bouts. As-fed inclusion rates for ingredients in the TMR for UNBAL cows were the same as for control cows, but as-fed rates were adjusted for the BAL treatment to achieve the same diet as the control treatment on a DM basis.

${ }^{3}$ Standard error of the difference.

${ }^{4}$ Contrasts: $\mathrm{C}$ vs. $\mathrm{U}=$ control versus UNBAL; $\mathrm{C}$ versus $\mathrm{B}=$ control versus BAL.

${ }^{5}$ Monounsaturated isomer divided by the sum of the monosaturated and saturated isomers.

BAL cows compared with control cows even though total water intake did not differ. The amount of water consumed with the diet was greater than the controls for both BAL and UNBAL cows. The increase in feed water intake $(2.8 \mathrm{~kg} / \mathrm{d})$ was probably compensated by a smaller, but statistically nonsignificant decrease in free water intake (Table 6).

Digestibility of DM, NDF, starch, and N was not affected by treatment (Table 6). We hypothesized that an abrupt change in carbohydrate balance (greater starch concentration and lower fiber concentration in the UNBAL diet) caused by adding water to the silage would cause a transient change in the rumen environment and disrupt the bacterial population and reduce digestibility, especially that of NDF. No differences in NDF digestibility were observed; however, OM digestibility was lower for both UNBAL $(P<0.06)$ and BAL $(P<$ $0.02)$ cows than control cows. The nutrient fractions responsible for the depressed OM digestibility are not known but changes in digestibility of starch, NDF, and $\mathrm{CP}$ was not responsible for the change in OM digestibility. Digestibility of OM can decrease with increasing DMI (Huhtanen et al., 2009) and that could explain the depressed OM digestibility for the UNBAL treatment but not the BAL effect. Both the in vivo (Table 6) and the 30-h in vitro NDF digestibility for the TMR (Table 2) were similar across treatment and in vitro digestibility averaged about $94 \%$ of the in vivo values.

Nitrogen metabolism was not affected by treatment (Table 6). Because of greater DMI during the digestion 
Table 6. Effects of feeding wetted silage to cows on digestibility and water intake $(\mathrm{n}=6 /$ treatment $)$

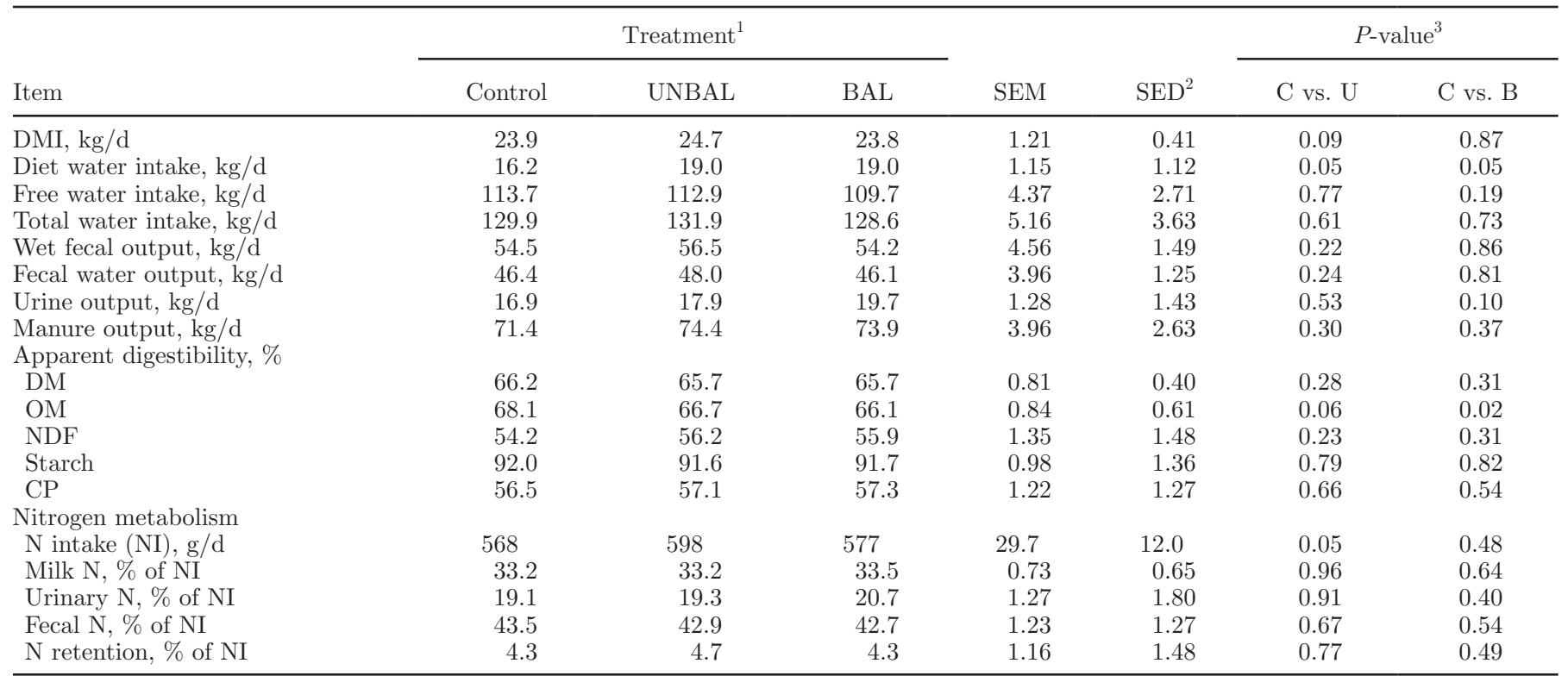

${ }^{1}$ The control diet was fed to control cows at all times and to all other cows during the non-change periods. Cows on unbalanced (UNBAL) and balanced (BAL) diets were fed a mix of wetted silage during two 3-d bouts. As-fed inclusion rates for ingredients in the TMR for UNBAL cows were the same as for control cows, but as-fed rates were adjusted for the BAL treatment to achieve the same diet as the control treatment on a DM basis. Data in this table are from the 4 -d total collection period conducted, starting on $\mathrm{d} 1$ of the first bout and ending $1 \mathrm{~d}$ after the bout ended.

${ }^{2}$ Standard error of the difference.

${ }^{3}$ Contrasts: $\mathrm{C}$ vs. $\mathrm{U}=$ control versus UNBAL; $\mathrm{C}$ vs. $\mathrm{B}=$ control versus BAL.

trial, cows on the UNBAL diet consumed more $\mathrm{N}$ than control cows $(P<0.05)$. Cows on UNBAL also secreted more milk $\mathrm{N}$ per day than control cows $(P<0.02$; data not shown), but when milk, urine, and fecal $\mathrm{N}$ were expressed as a percent of $\mathrm{N}$ intake, no treatment effects were observed (Table 6).

\section{CONCLUSIONS}

Cows on a treatment regimen that included 2 transient 3-d bouts when they were fed wetted silage (silage DM concentration decreased by 10 percentage units) had similar milk yields as cows fed a consistent diet over a 21-d period when the as-fed inclusion rate of the silage in the TMR was adjusted to keep the diets equal on a DM basis. Cows experiencing the same transient bouts but without adjusting the silage inclusion rate had greater milk production than those fed a consistent diet (likely a reflection of increased concentrate intake during those bouts). Dry matter intake was generally depressed the first day the wetted silage was fed but then DMI by cows fed the wetted silage was greater than that of control cows the day following the bouts of wetted silage. Decreased OM digestibility and some small changes in milk FA profiles are suggestive of a limited disruption of normal rumen function by cows fed either BAL or UNBAL diets. Unexpectedly, this response was generally greater for BAL than UNBAL diets even though for the UNBAL diet, concentrations of DM, starch, NDF, and forages changed, whereas for the BAL treatment only DM concentration changed.

\section{ACKNOWLEDGMENTS}

This project was supported by National Research Initiative Competitive Grant no. 2009-55206-05242 from the US Department of Agriculture National Institute of Food and Agriculture (Washington, DC).

\section{REFERENCES}

Allen, M. S. 2000. Effects of diet on short-term regulation of feed intake by lactating dairy cattle. J. Dairy Sci. 83:1598-1624.

Allen, M. S., B. J. Bradford, and M. Oba. 2009. Board-Invited Review: The hepatic oxidation theory of the control of feed intake and its application to ruminants. J. Anim. Sci. 87:3317-3334.

AOAC International. 2000. Official Methods of Analysis. 17th ed. AOAC International, Washington, DC.

Baumgard, L. H., E. Matitashvili, B. A. Corl, D. A. Dwyer, and D. E. Bauman. 2002. trans-10, cis-12 conjugated linoleic acid decreases lipogenic rates and expression of genes involved in milk lipid synthesis in dairy cow. J. Dairy Sci. 85:2155-2163.

Boyd, J., and D. R. Mertens. 2010. Abrupt changes in forage dry matter of one to three days affect intake and milk yield in early lactation dairy cows. J. Dairy Sci. 93(E-Suppl. 1):514. (Abstr.) 
Boyd, J., and D. R. Mertens. 2011. Abrupt changes in forage dry matter of one to three days affect intake and milk yield in late lactation dairy cows. J. Dairy Sci. 94(E-Suppl. 1):378. (Abstr.)

Cabrita, A. R. J., R. J. B. Bessa, S. P. Alves, R. J. Dewhurst, and A. J. M. Fonseca. 2007. Effects of dietary protein and starch on intake, milk production, and milk fatty acid profiles of dairy cows fed corn silage-based diets. J. Dairy Sci. 90:1429-1439.

Colman, E., W. B. Fokkink, M. Craninx, J. R. Newbold, B. De Baets, and V. Fievez. 2010. Effect of induction of subacute ruminal acidosis on milk fat profile and rumen parameters. J. Dairy Sci. 93:4759-4773.

Fievez, V., E. Colman, M. M. Rahman, J. C. Montoya, I. Stefanov, F. Gadeyne, and B. Vlaeminck. 2011. Use of fatty acids in milk of dairy cattle as a diagnostic tool for metabolic diseases, methane emissions and rumen function. Pages 193-205 in Proc. Eastern Nutr. Conf., Montreal, Quebec, Canada. Anim. Nutr. Assoc. of Canada, Ottawa, Ontario, Canada.

Fish. J. A., and T. J. DeVries. 2012. Short communication: Varying dietary dry matter concentration through water addition: Effect on nutrient intake and sorting of dairy cows in late lactation. J. Dairy Sci. 95:850-855.

Goering, H. K., and P. J. Van Soest. 1970. Forage fiber analysis. Agric. Handbook 379. US Department of Agriculture, Washington, DC.

Griinari, J. M., D. A. Dwyer, M. A. McGuire, D. E. Bauman, D. L. Palmquist, and K. V. V. Nurmela. 1998. Trans-octadecenoic acids and milk fat depression in lactating dairy cows. J. Dairy Sci. $81: 1251-1261$.

Harvatine, K. J., and D. E. Bauman. 2006. SREBP1 and thyroid hormone responsive spot 14 (S14) are involved in the regulation of bovine mammary lipid synthesis during diet-induced milk fat depression and treatment with CLA. J. Nutr. 136:2468-2474.

Huhtanen, P., M. Rinne, and J. Nousiainen. 2009. A meta-analysis of feed digestion in dairy cows. 2 . The effects of feeding level and diet composition on digestibility. J. Dairy Sci. 92:5031-5042.

Ipharraguerre, I. R., and J. H. Clark. 2003. Soyhulls as an alternative feed for lactating dairy cows: A review. J. Dairy Sci. 86:10521073.

Jenkins, T. C. 2000. Feeding oleamide to lactating Jersey cows. 1. Effects on lactation performance and milk fatty acid composition. J. Dairy Sci. 83:332-337.

Kohn, R. A., K. F. Kalscheur, and E. Russek-Cohen. 2002. Evaluation of models to estimate urinary nitrogen and expected milk urea nitrogen. J. Dairy Sci. 85:227-233.
Leonardi, C., F. Giannico, and L. E. Armentano. 2005. Effect of water addition on selective consumption (sorting) of dry diets by dairy cattle. J. Dairy Sci. 88:1043-1049.

Mertens, D. R., and P. Berzaghi. 2009. Short-term changes in forage dry matter affect milk production responses in dairy cows. J. Dairy Sci. 92(E-Suppl. 1):583. (Abstr.)

NRC. 2001. Nutrient Requirements of Dairy Cattle. 7th rev. ed. Natl. Acad. Press, Washington, DC.

Peterson, D. G., E. A. Matitashvili, and D. E. Bauman. 2003. Diet-induced milk fat depression in dairy cows results in increased trans-10, cis-12 CLA in milk fat and coordinate suppression of mRNA abundance for mammary enzymes involved in milk fat synthesis. J. Nutr. 133:3098-3102.

Robinson, P. H., P. L. Burgess, and R. E. McQueen. 1990. Influence of moisture content of mixed rations on feed intake and milk production of dairy cows. J. Dairy Sci. 73:2916-2921.

Shaver, R. 2004. Feeding programs in high producing dairy herds. Pages 143-170 in Proc. Tri-State Dairy Nutr. Conf., Fort Wayne, IN. The Ohio State Univ., Columbus.

Van Soest, P. J., J. B. Robertson, and B. A. Lewis. 1991. Methods for dietary fiber, neutral detergent fiber, and nonstarch polysaccharides in relation to animal nutrition. J. Dairy Sci. 74:3583-3597.

Vlaeminck, B., V. Fievez, A. R. J. Cabrita, A. J. M. Fonseca, and R. J. Dewhurst. 2006a. Factors affecting odd-and branched-chain fatty acids in milk: A review. Anim. Feed Sci. Technol. 131:389-417.

Vlaeminck, B., V. Fievez, S. Tamminga, R. J. Dewhurst, A. van Vuuren, D. De Brabander, and D. Demeyer. 2006b. Milk odd- and branched-chain fatty acids in relation to the rumen fermentation pattern. J. Dairy Sci. 89:3954-3964.

Weiss, W. P., D. E. Shoemaker, L. R. McBeth, P. Yoder, and N. R. St-Pierre. 2012. Within farm variation in nutrient composition of feeds. Pages 103-117 in Proc. Tri-State Dairy Nutr. Conf., Fort Wayne, IN. The Ohio State Univ., Columbus.

Weiss, W. P., N. R. St-Pierre, and L. B. Willett. 2009. Varying type of forage, concentration of metabolizable protein, and source of carbohydrate affects nutrient digestibility and production by dairy cows. J. Dairy Sci. 92:5595-5606.

Weiss, W. P., and D. J. Wyatt. 2000. Effect of oil content and kernel processing of corn silage on digestibility and milk production by dairy cows. J. Dairy Sci. 83:351-358.

Weiss, W. P., and D. J. Wyatt. 2003. Effect of dietary fat and vitamin $\mathrm{E}$ on $\alpha$-tocopherol in milk from dairy cows. J. Dairy Sci. $86: 3582-3591$. 